improved gradually after the discontinuation of FK506 (22 February) without any additional treatment.

The trough level of FK506 in whole blood in our cases was maintained below $20 \mathrm{ng} / \mathrm{ml}$, the level recommended to prevent adverse side effects ${ }^{2}$ (table)

The level of $Q$ albumin, used as an indicator of blood-brain-barrier (BBB) function, increased with administration of FK506 and decreased rapidly after discontinuation. The level of FK506 in the CSF showed the same trend as $Q$ albumin (table), suggesting that there was a shift of FK506 from blood to CSF caused by an accelerated permeability of the BBB. It is not clear whether the acceleration of permeability of $\mathrm{BBB}$ was related to the fragility of the BBB in Behçet's disease or to the direct effect of FK506.

There are reports of other patients with Behçet's disease ${ }^{34}$ and transplant patients treated with cyclosporine who exhibited signs and symptoms similar to those experienced by our cases. The central nervous system symptoms experienced by these patients appeared to be related to cyclosporine because they were reversed by discontinuation of the drug. ${ }^{3} 4$

Taking into account these reports as well as the resemblance of FK506 to cyclosporine in its effects on the immune system, ${ }^{56}$ there appears to be a relationship between the onset of the CNS symptoms and the administration of FK506.

The findings in our cases suggest that FK506 may cause a CNS toxicity that resembles neuro-Behçet's disease especially in patients with Behçet's disease. The possibility of a central nervous system disorder should be considered when patients with Behçet's disease are treated with FK506.

T IGARASHI Y ISHIGATSUBO S OHNO A UEDA T OKUBO The First Department of Internal Medicine,
Yokohama City University School of Medicine, Japan

$S$ TANAKA The Third Department of Internal Medicine, Yokohama City University School of Medicine, Yokohama, fapan Y KATSUMATA
Radiology Department,
Yokohama City University School of Medicine,
Yokohama, Y KATSUMATA
Radiology Department,
Yokohama City University School of Medicine,
Yokohama, Japan

T SAKANE Institute of Medical Science, St Marianna University School of Medicine, Japan
awasak,

S OHNO Ophthalmology Department,

Yokohama City Universal Schoool of Medicine,
Yokohama,
fapan

Yokohama City Universal Schoool of Medicine,
Yokohama,
fapan

Correspondence to: $\mathrm{Dr} \mathrm{Y}$ Ishigatsubo, First Department of Internal Medicine, Yokohama City University School of Medicine, Fukuura 3-9, Kanazawa-ku, Yokohama 236, Japan.

1 Kawashima H, Fujino Y, Mochizuki M. Effects of a new immunosuppressive agent, FK506, on experimental autoimmune uveoretinitis in rats. Invest Ophthalmol Vis Sci 1988; 29: rats. Invest

2 Mochizuki M, Masuda K, Sakane T, et al. A multicenter clinical open trial of FK506 in refractory uveitis, including Behcet's disease. Transplant Proc 1991; 23: 3343-6.

3 Harada K, Tuboi E. Cyclosporin and Behçet's disease like syndrome. Ophthalmol 1991; 33: 491-6.
4 Pahlitzsch T, Wyrobish W, Kampe C. Cyclosporin A in Behçet's Disease. Klin $\mathrm{Mbl}$ Augenheilk 1990; 196: 466-9.

5 Steinmann B, Superti-Furga A, Bruckner P. Mechanism of action of FK506 and cyclosporin. Lancet 1991; 337: 439.

6 Starzl T E, Schneck S A, Mazzoni G, et al. Acute neurological complications after liver transplantation with particular reference to intraoperative cerebral air embolus. Ann Surg 1978; 187: $236-40$.

\section{High lipoprotein (a) levels as a thrombogenic risk factor in Behçet's disease}

Behçet's disease which is characterised by oral and genital ulcer and eye inflammation was discovered by Dr Hulusi Behçet in 1937. Other features include arthritis, thrombophlebitis, neurological abnormalities and skin lesions. Vascular manifestations, especially venous thrombosis, arteritis and aneurysm formations are not uncommon. ${ }^{1}$

Lipoprotein (a) is an LDL-like particle with a large glycoprotein called apolipoprotein (a) [apo (a)] attached to its apo B moiety through one or more disulphide bonding. Apo (a) is related to plasminogen from which the enzyme plasmin that hydrolyses fibrin blood clots is released by tissue plasminogen activators. ${ }^{2}$ The unique structural features of $\mathrm{Lp} \mathrm{(a),} \mathrm{give} \mathrm{it} \mathrm{the}$ potential for atherogenic and thrombogenic activities. $^{3}$ We have studied Lp (a) level in Behçet's disease.

The study group included 22 patients with Behçet's disease (10 men and 12 women with a mean age of $31 \cdot 4$, age range: $18-55)$ and 20 healthy volunteers (10 men and 10 women with a mean age of 30.5 , age range: 18-52). The groups were matched for factors influencing lipoprotein levels such as diet, body mass and exercise. Oral apthous lesions and genital ulcerations were found in all

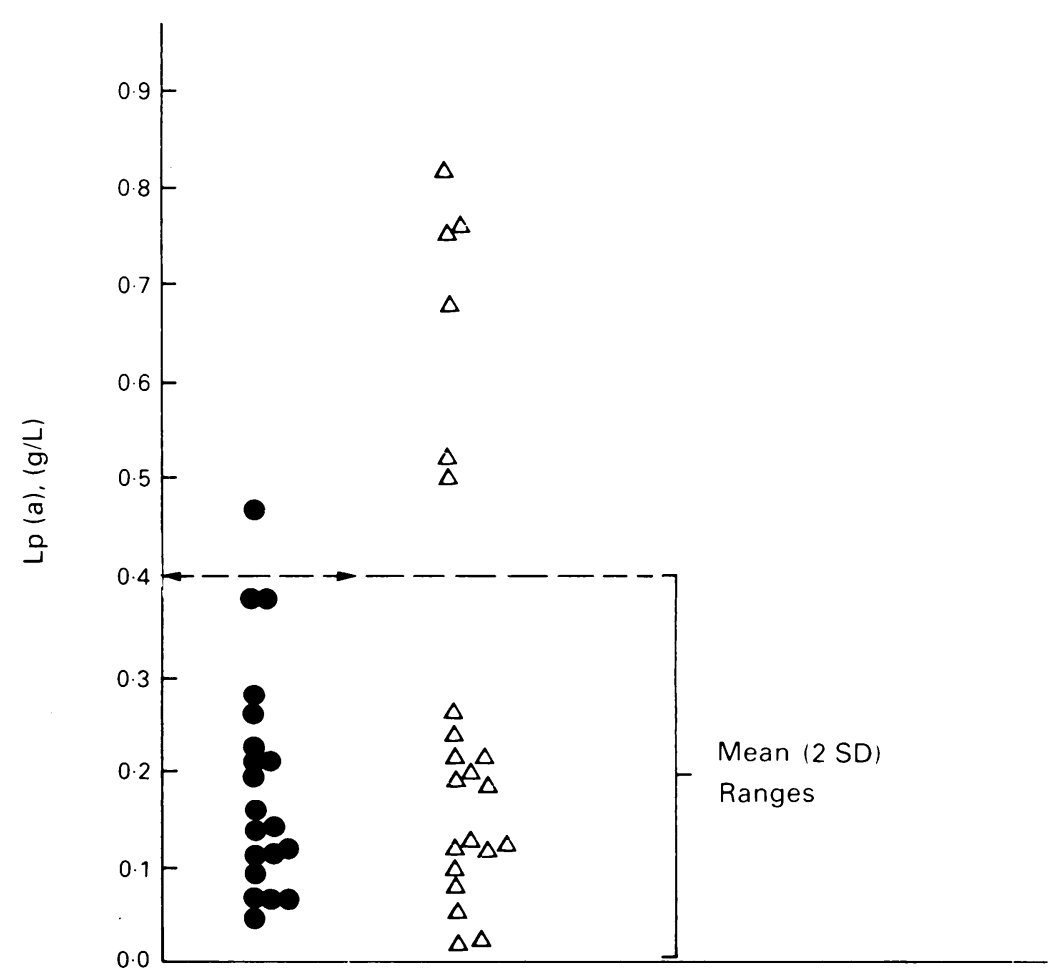

Serum Lp (a) concentrations in patients with Behçet's disease and in controls (O shows controls, $\triangle$ shows patients).
Plasma Lp (a), lipids, and lipoprotein levels in patients with Behcet's disease and in control group

\begin{tabular}{|c|c|c|}
\hline Parameters & $\begin{array}{l}\text { Controls } \\
\text { Mean (2SD) } \\
(n=20)\end{array}$ & $\begin{array}{l}\text { Patients } \\
\text { Mean (2SD) } \\
(n=22)\end{array}$ \\
\hline $\mathrm{Lp}(\mathrm{a}), \mathrm{g} / \mathrm{L}$ & $0.19(0.11)$ & $0.30(0.28)^{\star}$ \\
\hline Apo AI, $g / L$ & $1.23(0.21)$ & $1.00(0.09) \ddagger$ \\
\hline Apo $B, g / L$ & $0.72(0.17)$ & $1.03(0.10) \ddagger$ \\
\hline $\begin{array}{l}\text { Total cholesterol, } \\
\mathrm{mmol} / \mathrm{L}\end{array}$ & $4.91(1.04)$ & $4.81(0.91)^{+}$ \\
\hline $\begin{array}{l}\text { Triglycerides, } \\
\mathrm{mmol} / \mathrm{L}\end{array}$ & $1.39(0.41)$ & $1.10(0.37) \dagger$ \\
\hline $\mathrm{HDL}-\mathrm{C}, \mathrm{mmol} / \mathrm{L}$ & $1.37(0.08)$ & $1.18(0.09) \ddagger$ \\
\hline $\mathrm{LDL}-\mathrm{C}, \mathrm{mmol} / \mathrm{L}$ & $2.91(0.96)$ & $3.09(0.80)$ \\
\hline
\end{tabular}

${ }^{\star} \mathrm{p}<0.05,+\mathrm{p}<0.01, \neq \mathrm{p}<0.001$, patients $\mathrm{v}$ controls (according to Mann-Whitney U test or student's $t$ test).

patients. Uveitis in $12(54.5 \%)$ patients and dermatological lesions (erythema nodosum, pyoderma, folliculitis) in $22(100 \%)$ patients were recognised. Arthralgia or arthritis-like joint involvement occurred in $13(59 \%)$ patients. At the time of the study, patients were being treated with either colchicine $(n=4)$, or non-steroid anti-flammatory drugs (NSAIDs) $(\mathrm{n}=7)$, or colchicine plus NSAIDs $(n=2)$, while the remaining nine patients were receiving no systemic medication.

Serum total cholesterol, triglycerides, HDL-cholesterol and apolipoproteins A-I and $B$ were measured by routine clinical methods. LDL-cholesterol was calculated by Friedewald formula. Lp (a) was measured using a commercial anti-apo (a) polyclonal capture enzyme-linked immunosorbent assay called TintEliza lipoprotein (a) (Biopool AB, Umea, Sweden).

The concentrations of plasma Lp (a), lipids and apolipoproteins in patients with Behçets disease and in controls are shown in the table. The Lp (a) concentration was significantly higher in patients with Behçet's disease compared with the controls $(p<0 \cdot 05)$. As seen in the figure, six patients (four of them 
complete) had higher Lp (a) levels than reference ranges [mean (2SD)]. There was no significant correlation between $\operatorname{Lp}$ (a) and other parameters in patients with Behçet's disease.

In the present study, the concentration of $\mathrm{Lp}$ (a) was significantly increased in patients with Behçet's disease. Increased raised levels of $\mathrm{Lp}$ (a) increase the risk of atherogenic and thrombogenic events. ${ }^{2}{ }^{3}$

Behçet's syndrome is an uncommon systemic vasculitic disorder complicated in about one third of cases by venous thrombosis. ${ }^{4}$ The basis of the thrombotic risk in Behçet's disease is not understood. The reduced fibrinolytic activity well reported in this syndrome may contribute to these thrombotic events. ${ }^{5}$ In vitro and ex vivo studies have shown that $\mathrm{Lp}$ (a) can bind to immobilised fibrin (fibrinogen), fibronectin receptor in monocytes, and glycosaminoglycan of the type present in the arterial wall and can also compete with tissue plasminogen activator in converting plasminogen to plasmin. $^{67}$ Recent studies have suggested that increased Lp (a) concentration may inhibit fibrinolysis by reducing the generation of plasmin by different mechanisms; (a) competing for plasminogen cell-surface receptors, (b) inhibiting activation of plasminogen, and (c) competing for binding sites on fibrin. ${ }^{8}$

The finding of raised $\mathrm{Lp}$ (a) in Behçet's disease in this preliminary study may have detected a thrombogenic risk factor for this disease. Further studies are in progress.

ASIM ÖREM
ORHAN DEĞER
Department of Biochemistry
ÖZCAN MEMIS
KÜRSAT CALISKAN
GÜLSEREN CiMSIT
Department of Dermatology
Faculty of Medicine, Karadeniz Technical University,
Trabzon, Turkey

Correspondence to: Dr Asım Örem, KTÜ Tıp Fakültesi Biyokimya Anabilim Dalı, 61080, Trabzon, Turkey

1 Michelson J B, Friedlaender M H. Behçet's disease. Inter Ophthal Clin 1990; 30: 271-8.

2 McLean J W, Tomlinson J E, Kuang W I, et al. cDNA sequence of human apolipoprotein (a) is homologous to plasminogen. Nature 1987; 300: 132-7.

3 Scanu A M. Lipoprotein (a): a potential bridge between the fields of atherosclerosis and thrombosis. Arc Pathol Lab Med 1988; 112: 1045-7.

4 Samlaska C P, James W D. Superficial thrombophlebitis II seconda hypercoagulable thromboph Am Acad Dermatol 1990; 23: states.

5 Schiff S, Moffatt R, Mandel W J, Rubin S A. Acute myocardial infarction and $S$ A. Acute myocardial infarction and recurrent ventricular arrhythmias in
Behçet's syndrome. Am Heart $\mathcal{f} 1982 ; 103$ :

6 Aitchison R, Chu P, Cater D R, Harris J, Powell R J. Defective fibrinolysis in Behçet's syndrome: significance and possible mechanisms. Ann Rheumatic Disease 1989; 48 590-3.

7 Brown D L, Phillips E R, Damsky C H Synthesis and expression of the fibroblast fibronectin receptor in human monocyte. fClin Invet 1989; 84: 366-70

8 Ehnholm C, Jauhiaineu M, Metso J. Interaction of lipoprotein (a) with fibronectin and its potential role in atherogenesis. Europ Heart $f$ 1990; 11: 190-5.

9 Heinrich J, Sandkamp M, Kokott R, Schute H, Assmann G. Relationship of lipoprotein (a) variables of coagulation and fibrinolysis in a healthy population. Clin Chem 1991; 37: 1950-4.

\section{Absence of an association between antibodies to retroviral proteins and anticardiolipin antibody and/or lupus anticoagulant in systemic lupus erythematosus}

Some researchers have reported finding antibody(ies) reactive to human immunodeficiency virus (HIV) and/or human T cell leukaemia virus type 1 (HTLV-1) in patients with systemic lupus erythematosus (SLE) ${ }^{1-5}$ Anticardiolipin antibody (aCL) and/or lupus anticoagulant (LA) are also frequently detected in patients with HIV-1 infection. ${ }^{\circ}$ We conducted this study to discover whether there is a close association between positivities of $\beta_{2}$-glycoprotein I-dependent aCL (GPI-aCL) and LA and the presence of retrovirus antibodies in SLE.

The subjects included 50 patients with SLE aged 20-40 years (46 women and four men), who fulfilled the criteria of the American College of Rheumatism Association for the diagnosis of SLE. Ten patients with syphilis and 20 healthy laboratory and hospital staff members (aged 22-43 years) (all women) served as disease and healthy controls, respectively. None of the subjects came from the HTLV-1 endemic area in

Antibodies reacting with human retroviral proteins on Western blot in the sera of patients with systemic lupus erythematosus, patients with syphilis and healthy controls

\begin{tabular}{|c|c|c|c|c|c|}
\hline & \multicolumn{5}{|l|}{$S L E$} \\
\hline & \multicolumn{2}{|c|}{ aCL/LA-positive } & & \multicolumn{2}{|l|}{ aC $/ L / L A-n$-native } \\
\hline & $H I V-1$ & $H T L V-1$ & & $H I V-1$ & $H T I, V-I$ \\
\hline $\begin{array}{c}\mathrm{aCL} \\
\mathrm{C}-1 \\
\mathrm{C}-2 \\
\mathrm{C}-3 \\
\mathrm{C}-4 \\
\mathrm{C}-5 \\
\mathrm{C}-6 \\
\mathrm{C}-7 \\
\mathrm{C}-8 \\
\mathrm{C}-9 \\
\mathrm{C}-10 \\
\mathrm{C}-11 \\
\mathrm{C}-12 \\
\mathrm{C}-13\end{array}$ & $\begin{array}{l}\text { P18 } \\
\text { P25, P52 } \\
\text { P40 } \\
\text { P68 } \\
(-) \\
(-) \\
(-) \\
(-) \\
(-) \\
(-) \\
(-) \\
(-) \\
(-)\end{array}$ & $\begin{array}{l}\text { P53 } \\
\text { gP68 }\end{array}$ & $\begin{array}{l}\mathrm{N}-1 \\
\mathrm{~N}-2 \\
\mathrm{~N}-3 \\
\mathrm{~N}-4 \\
\mathrm{~N}-5 \\
\mathrm{~N}-6 \\
\mathrm{~N}-7 \\
\mathrm{~N}-8 \\
\mathrm{~N}-9 \\
\mathrm{~N}-10 \\
\mathrm{~N}-11 \\
\mathrm{~N}-12 \\
\mathrm{~N}-13 \\
\mathrm{~N}-14\end{array}$ & $\begin{array}{l}\text { P18, P25 } \\
\text { P18, P25 } \\
\text { P18, P68 } \\
\text { P25, P52, P55 } \\
\text { P25, P52 } \\
\text { P40, P52 } \\
\text { P40 } \\
\text { P52, P68 } \\
\text { P52, P68 } \\
\text { P52 } \\
\text { P52 } \\
\text { gP41, P52 } \\
\text { gP41, P55 } \\
(-)\end{array}$ & $\begin{array}{l}P 28 \\
P 53\end{array}$ \\
\hline $\begin{array}{c}\text { LA } \\
\text { L-1 } \\
\text { L-2 } \\
\text { L-3 } \\
\text { L-4 } \\
\text { L-5 } \\
\text { L-6 } \\
\text { L-7 }\end{array}$ & $\begin{array}{l}\text { P25 } \\
\text { P25 } \\
\text { P25 } \\
\text { P25 } \\
\text { P52, P55 } \\
(-) \\
(-)\end{array}$ & & $\begin{array}{l}N-15 \\
N-16 \\
N-17 \\
N-18 \\
N-19 \\
N-20 \\
N-21 \\
N-22\end{array}$ & $\begin{array}{l}(-) \\
(-) \\
(-) \\
(-) \\
(-) \\
(-) \\
(-) \\
(-)\end{array}$ & \\
\hline $\begin{array}{c}\text { aCL/LA } \\
\text { CL-1 } \\
\text { CL-2 } \\
\text { CL-3 } \\
\text { CL-4 } \\
\text { CL-5 } \\
\text { CL-6 } \\
\text { CL-7 }\end{array}$ & $\begin{array}{l}\text { P25 } \\
\text { P25 } \\
\text { P40 } \\
(-) \\
(-) \\
(-) \\
(-)\end{array}$ & P19 & $N-23$ & $(-)$ & \\
\hline & Syphilis & & & Healthy & \\
\hline & $H I V-1$ & $H T L V-1$ & & $H I V-1$ & $H T L V-1$ \\
\hline $\begin{array}{l}\text { S-1 S-5 } \\
\text { S-6 } \\
\text { S-7 } \\
\text { S-8 } \\
\text { S-9 }- \text { S-10 }\end{array}$ & $\begin{array}{l}\text { P25 } \\
\text { P25, P55 } \\
\text { P34 } \\
(-) \\
(-)\end{array}$ & P28 & $\begin{array}{l}\mathrm{H}-1 \sim \mathrm{H}-3 \\
\mathrm{H}-4 \\
\mathrm{H}-5 \sim \mathrm{H}-6 \\
\mathrm{H}-7 \sim \mathrm{H}-8 \\
\mathrm{H}-9 \sim \mathrm{H}-20\end{array}$ & $\begin{array}{l}\text { P25 } \\
\text { P34 } \\
\text { P55 } \\
(-) \\
(-)\end{array}$ & P28 \\
\hline
\end{tabular}

$\mathrm{aCL}=$ anti-cardiolipin antibody; $\mathrm{LA}=$ lupus anticoagulant; $\mathrm{HIV}-1$ = human immunodeficiency virus type 1 ; HTLV-1 $=$ human $T$ cell leukaemia virus type $1 ; C-1-13=a C L$-positive; L-1-7 = LA-positive; CI $1-7=\mathrm{aCL}$ - and LA-positive; $\mathrm{S}-1-10=$ patients with syphilis; $\mathrm{H}-1-20=$ healthy controls

western Japan. GPI-aCL in the serum was measured by previously reported methods, and LA in platelet-depleted plasma was measured by modified methods of Exner al." Determination of antibodies to retroperformed by Western immunoblotting using a test kit of LAV BLOT 1 (Fujirebio, Japan) for HIV-1 and a test kit of Eitest ATL-WB (Eisai, Japan) for HTLV-1 according to the manufacturers instructions.

GPI-aCL and LA were positive in $20 / 50$ $(40 \%)$ and $14 / 50(28 \%)$ of patients with positive for both aCL/LA. None of the patients with syphilis was positive for GPI-aCL and LA.

Six of $20(30 \%)$ healthy controls and seven of $10(70 \%)$ patients with syphilis were positive for at least one of the HIV-1 retroviral proteins (table, figure). Twenty three of $50(46 \%)$ overall SLE patients with SLE were positive for the HIV-1 retroviral proteins. Twelve of 27 (44\%) GPI-aCl positive LA-positive patients with SLE were Thirteen of $23(57 \%)$ aCL and/or LAnegative patients with SLE were positive for HIV-1 proteins, showing the higher positivity than aCL/LA positive group. Antibodies to HTLV-1 viral proteins were positive in $1 / 20$ $(5 \%)$ healthy controls, $1 / 10(10 \%)$ syphilis patients, and $7 / 50(12 \%)$ overall SLF patients $[3 / 27(11 \%) \mathrm{aCL}$ and/or LA-positive

,

